\title{
Acute toxicity evaluation of homeopathic preparation of Gymnema sylvestre and analysis of its chemical constituents
}

\author{
Avanish Shukla ${ }^{1 *}$, Imtiaz Khalid Muhammed ${ }^{2}$, Ravi Sheshala ${ }^{3}$, Ibrahim Usman Mhaisker ${ }^{1}$, Krishna Rampal $^{4}$ \\ ${ }^{1}$ Faculty of Traditional and Complementary Medicine, Cyberjaya University College of Medical Science, Cyberjaya, Malaysia \\ ${ }^{2}$ Department of Pharmaceutical Chemistry, Faculty of Pharmacy, Cyberjaya University College of Medical Science, Cyberjaya, Malaysia \\ ${ }^{3}$ Faculty of Pharmacy, University Teknologi MARA UiTM, Puncak Alam, Malaysia \\ ${ }^{4}$ Centre for Graduate Studies, Research and Commercialization, Cyberjaya University College of Medical Science, Cyberjaya, Malaysia
}

\begin{tabular}{l}
\hline ARTICLE INFO \\
\hline Article history: \\
Received on: November 05, 2019 \\
Accepted on: February 05, 2020 \\
Available online: July 30, 2020 \\
\hline
\end{tabular}

Key words:

Gymnema sylvestre, homeopathy, toxicity, LC/MS,

Sprague Dawley rats

\section{ABSTRACT}

In many countries, homeopathic preparation is believed to be an effective medicine for various ailments. However, there are limited scientific evidences in regard to its usage, safety, and efficacy. It is necessary to update this age-old scientific wisdom in different aspects, including pharmacologic and therapeutic potentials. In this study, we assessed the safety profile of homeopathic preparation of Gymnema sylvestre (HPGS). Its chemical constituents were deciphered using LCMS approaches. HPGS was subjected to an acute toxicity study (OECD-423 guidelines) using Sprague Dawley rats. The administration of HPGS did not produce any toxic symptoms or show mortality at the dose level of $300 \mathrm{mg} / \mathrm{kg}$ body weight. Phytochemical analysis revealed that HPGS contained alkaloids, saponins, and flavonoids. These results demonstrated the non-toxic nature of HPGS in vivo, suggesting a long-term usage in clinical practices when administered orally.
\end{abstract}

\section{INTRODUCTION}

Gymnema sylvestre (Retz.) R.Br. ex Schult is a medicinal plant belonging to family Asclepiadaceae [1]. Generally, it is named as Meshashringi, Madhunashini (Sanskrit); Gur-mar, Merasingi (Hindu); Marathi: Kavali, Kalikardori, Vakundi (Marathi); Dhuleti, Mardashingi (Gujrathi); Podapatri (Telugu); Tamil: Adigam, Cherukurinja (Tamil); Sannagerasehambu (Kannada). This slow growing, perennial, and woody climber is native to Africa, Asia, Australia, and India. It has been documented in Ayurvedic system of medicine for diabetes and other disorders, such as coughing and eye pain [2].

Homeopathy is a traditional remedy based on the fundamental idea of "Similarity Principle" implying that any substances capable of causing illness in a healthy subject can be used as medicines to treat similar patterns of symptoms experienced by an ill individual [3]. There are several forms of homeopathy, including "individualized homeopathy', “clinical

\footnotetext{
*Corresponding Author

Avanish Shukla, Faculty of Traditional and Complementary Medicine, Cyberjaya University College of Medical Science, Cyberjaya, Malaysia. E-mail:dr.avishukla@hotmail.com
}

homeopathy," and "isopathy." In individualized homeopathy (or classical homeopathy), a single homeopathic preparation is chosen on the basis of the "total symptom picture" covering physical, mental, and emotional symptoms of a patient. The homeopathic preparation is typically manufactured through a proprietary trituration, dilution, and succussion of raw material.

Gymnema sylvestre extract has been demonstrated to show anti-diabetes activities [4]. A comprehensive review on its phytochemicals has also been conducted [5]. However, scientific evidence for its safety in homeopathic preparation is still lacking. This study aims to fulfill the knowledge gap by evaluating the safety profile of $G$. sylvestre preparation. Its chemical constituents were also deciphered.

\section{MATERIALS AND METHODS}

\subsection{Homeopathic Preparation of G. sylvestre (HPGS) Preparation}

HPGS was manufactured by Schwabe $(\mathrm{GmbH}$, Germany) and imported by Global Homeopathic Centre (Subang Jaya, Malaysia). It was provided as a mother tincture formulation. Working HPGS was prepared freshly as an oral suspension during the dosing day. It was a mixture of $0.34 \mathrm{ml} \mathrm{HPGS}$ and $10 \mathrm{ml}$ pre- 
filtered water. The preparation was adopted from the work of Surender et al. [6] where mother tincture were diluted with water prior to administration to rats in vivo.

\subsection{Experimental Animals}

Nine female Sprague Dawley rats were obtained from the Animal Breeding Centre, Faculty of Science and Technology, Universiti Kebangsaan Malaysia (UKM). All rats were about 4-6 weeks old weighing between 257.23 and $291.42 \mathrm{~g}$. They were kept in Makmal Bioserasi, UKM. The experiment model was approved by the UKM Animal Ethnic Committee. Each rat was housed alone in polycarbonate cages at $19^{\circ} \mathrm{C}-24^{\circ} \mathrm{C}$. Food and water was given ad libitum. All rats were acclimatized for 5 days prior to testing.

\subsection{Acute Oral Toxicity Study}

Acute toxicity assessment was carried out according to OECD 423 guideline under ISO 17,025 compliance at Prima Nexus Accessory Technical Laboratory. The study was conducted on two groups of rats $(n=3)$ using a stepwise procedure. In the first step, three rats, as test group (TG), were administered orally with single dose of HPGS at $300 \mathrm{mg} / \mathrm{kg}$ body weight in $10 \mathrm{mg} / \mathrm{kg}$ vehicle (pre-filtered distilled water). Three additional rats, as control group (CG), were administered with pre-filtered distilled water only $(10 \mathrm{ml} / \mathrm{kg})$. Clinical effects on the animals were observed at 30 minutes, hourly up to 4 hours and at 6 hours of post dosing, once daily for 14 days. The rat body weight was measured on day1, -7 and at termination (day-14). Gross necropsy was performed on both the TG and $\mathrm{CG}$ animals following $\mathrm{CO}_{2}$ euthanasia at termination day. In the second step, three female rats (continuing test group, CTG) were administered orally with HPGS at $300 \mathrm{mg}$ / $\mathrm{kg}$ body weight in $10 \mathrm{ml} / \mathrm{kg}$ vehicle following the no observable adverse effect level (NOAEL) findings from the previously TG. The rats were observed at 30 minutes, hourly up to 4 hours and at 6 th hour and 8th hour post dosing for 24 hours. On day-2, the rats were sacrificed for necropsy.

\subsection{Phytochemical and Macronutrient Screening}

The presence of alkaloids, saponin, flavonoid, amino acid, protein, and carbohydrate in HPGS were detected based on established testing methods [7]. The qualitative results are expressed as $(+)$ for the presence and $(-)$ for the absence of phytochemical groups. Drangendorff test, Mayer's test, and Wagner test were used to access the presence of alkaloid qualitatively. Flavanoid and saponin were accessed by lead acetate test and foam test, respectively. Benedict's test and Molisch's test were used to access the presence of carbohydrate. Last, Million's test was used to access protein while ninhydrin test was used to access amino acid.

\subsection{QTOF-LC/MS Analysis}

The analysis by QTOF-LC/MS was carried out using an Agilent 6,200 series LCMS (QTOF) system (Agilent Technologies, Palo Alto, CA). The experiment was conducted at Prima Nexus Accessory Technical Laboratory. The HPLC separation was performed on a reversed-phase Zorbax SB-C18 column $(250 \times 4.6$ mm i.d. $5 \mu \mathrm{m}$ particle size, Agilent Technologies, Lexington, MA) at $25^{\circ} \mathrm{C}$. The mobile phase consisted of water with $0.1 \%$ formic acid and $0.3 \%$ ammonia (solvent $\mathrm{A}$ ) and methanol with $0.1 \%$ formic acid and $0.3 \%$ ammonia (solvent B) was applied with the following gradient: from 0 to 1 minute, $60 \%$ solvent $\mathrm{B}$; from 1 to 2 minutes, 95\% solvent B; $2-4.5$ minutes, $95 \%$ solvent $B$; $4.5-5.5$ minutes, $60 \%$ solvent $\mathrm{B}$; from 5.5 to 7.0 minutes, $60 \%$ solvent B. The flow rate was $0.8 \mathrm{ml}$ minutes $^{-1}$. Injection volume was 10 $\mu 1$. The ion trap mass spectrometer was operated in positive ion mode with a scanning range from 200 to $\mathrm{m} / z$ 800. In addition, the activation energy for the MS/MS experiment was set to $1.0 \mathrm{~V}$.

\section{RESULTS AND DISCUSSION}

\subsection{Acute Oral Toxicity Test}

The purpose of this study was to determine the adverse toxic effects in vivo following a single oral administration of HPGS. The experiment was performed on two groups of rats using a stepwise procedure. In the first step, three female rats TG were administered orally with HPGS at $300 \mathrm{mg} / \mathrm{kg}$ body weight in $10 \mathrm{ml} /$ $\mathrm{kg}$ vehicle. Three additional female rats $\mathrm{CG}$ were administered with pre-filtered water only $(10 \mathrm{ml} / \mathrm{kg})$. In the second step, three female rats CTG were administered orally with of HPGS at $300 \mathrm{mg} / \mathrm{kg}$ body weight in $10 \mathrm{ml} / \mathrm{kg}$ vehicle following the NOAEL findings from the previously TG. All animals in TG, CTG, and CG survived during the course of study period without clinical or toxic manifestation. They did not show any weight loss (Fig. 1). In addition, gross lesions in the brain, kidney, lung, liver, stomach, spleen, heart, and pancreas were not detected during necropsy (Fig. 2). An animal in TG showed significant high liver and heart weight as compared to another two animals from the same TG. However, no remarkable difference was observed in the mean percentage of organ to animal body weight between the TG and CG animals. Similar findings were reported by Ogawa et al. [8] whereby G. sylvestre leaf extract was non-toxic up to $563 \mathrm{mg} / \mathrm{kg} /$ days using Wistar rat model. The exposure-related changes in body-weight, in the food consumption, in the hematological examinations, or in the serum biochemical examinations were not observed. To the authors best knowledge, this is the first scientific report on the safety profile on HPGS, and thus served as a standard to evaluate its anti-diabetic properties in the coming study. The dose applied in this study was similar with the work of on the safety profile of various mother tincture preparation. Certified homeopathic practitioner barely used mother tincture directly, and most of the practice involved small dilution of mother tincture prior to administration. Hence, $300 \mathrm{mg} / \mathrm{kg}$ dose suggest that the preparation is relatively safe when administered by common practice under the prescription of certified practitioner. Yet, further testing at the higher dose level $(2,000 \mathrm{mg} / \mathrm{kg})$ is necessary in order to classify HPGS according to OECD Guideline 423

\subsection{Phytochemical and Macronutrient Screening}

Plants produce a high diversity of secondary metabolites with prominent protective functions against extreme climate, predators, and harmful pathogens [9]. These secondary metabolites, termed as phytochemicals, are well-known for their medicinal values [10]. Generally, the plant secondary metabolites can be divided into three distinct groups: terpenes, phenolics, or nitrogen- and sulphur-containing compounds. In this study, classes of phytochemicals in G. sylvestre preparation were screened for its potential pharmacological effects. As 


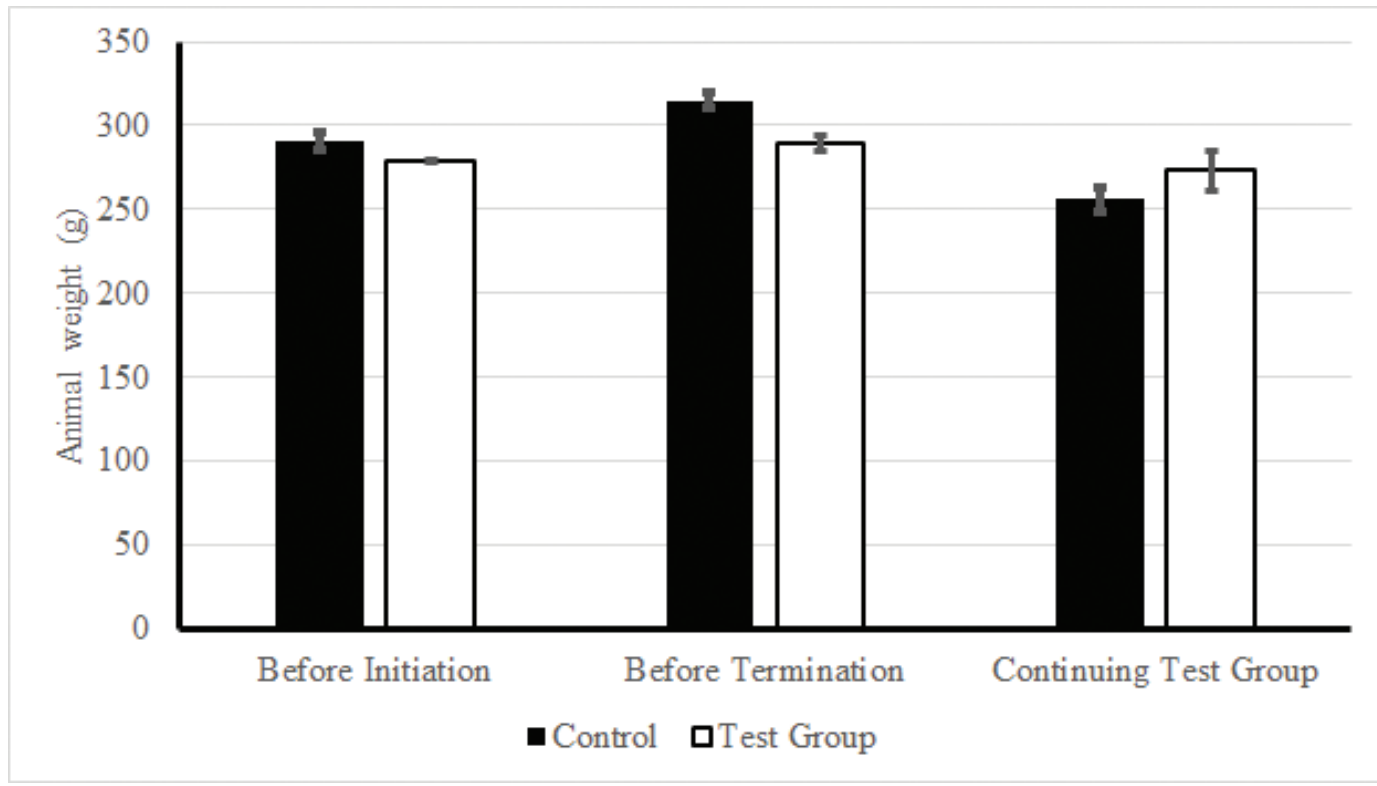

Figure 1: Weight of animal before initiation and termination of acute toxicity test.

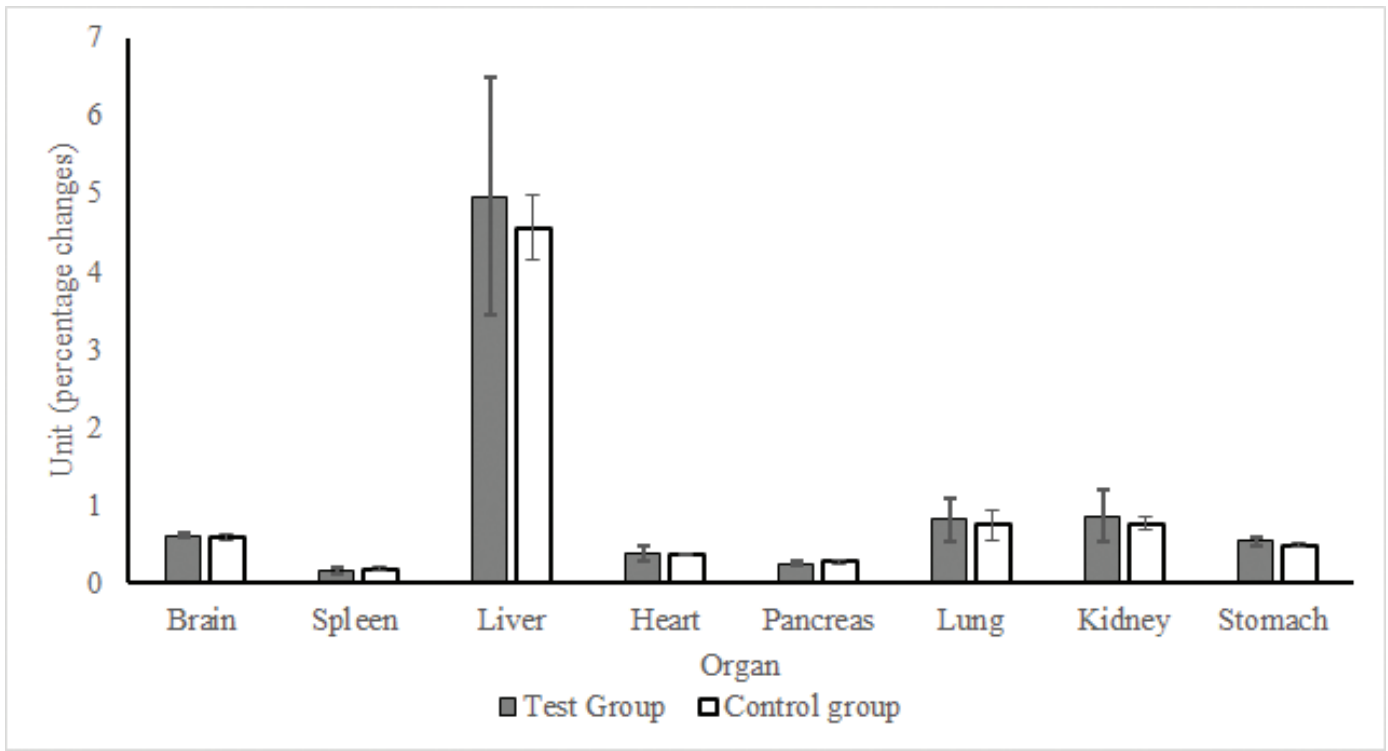

Figure 2: Comparison between test group and control group with regards of organ weight relative to animal body measured during necropsy.

tabulated in Table 1, secondary metabolites, including alkaloids, carbohydrates, flavonoids, proteins, and saponins were detected in HPGS. The finding was parallel with several reports dealing with G. sylvestre extract. For instance, alkaloids, cardiac glycoside, anthraquinone, tannins, phenols, saponins, and flavonoids were found in leaves part [11], whereas flavonoids, terpenoids, saponins, carbohydrates, and phenolics were found in root part [12]. Alkaloid, a nitrogen-containing compound, has been used as antiseptics, sedatives, and stomatics in Indian folk medicine [13]. Indeed, it possesses worthy pharmacological activities against inflammatory bowel disease [14] and neurodegenerative diseases [15]. There are numerous alkaloids derived from plant sources, such as atropine, berberine, sanguinarine, and quinidine [16]. On
Table 1: Phytochemical and macronutrient screening of HPGS.

\begin{tabular}{llll}
\hline Test & Observation & Inference & Phytochemicals \\
\hline Drangendorff test & Dark brown color & Negative & Alkaloid \\
Mayers test & Light yellow color & Positive & Alkaloid \\
Wagners test & Brown red color & Positive & Alkaloid \\
Benedict test & After heat color change & Positive & Carbohydrate/sugar \\
Molisch test & Purple and red ring & Positive & Carbohydrate \\
Millons test & Brown and red ring & Positive & Proteins \\
Ninhydrin & Brownish green color & Negative & Amino acids \\
Foam test & foam present & Positive & Saponins \\
Lead acetate test & Yellow color & Positive & Flavonoids \\
\hline
\end{tabular}


the other hand, flavonoids are phenolic compounds with diverse bioactivities, such as antioxidant, anti-inflammation, anticancer, and enzyme inhibition [17]. The compounds, including quercetin, rutin, hesperidin, and myricetin, can be obtained through dietary sources. A number of saponins, especially gymnemic acids has also been isolated from $G$. sylvestre [18]. Overall, HPGS contained several natural constituents with medicinal significances.

\subsection{QTOF-LC/MS Analysis}

The chemical constituents present in HPGS were analyzed through QTOF-LC/MS approach. Based on standard METLIN library information (e.g., peak retention times, UV spectrum, ESI-MS/MS data), we identified 36 compounds present in the HPGS (Table 2). As compare to the findings from Chodisetti et al. [25] and Tiwari et al. [18], sterols and lipid derivatives were the common phytochemical groups found in G. sylvestre. In this study, [24] 5,3',4'-trihydroxy-7-methoxy-4phenylcoumarin 5-O-(6"-acetyl)-galactoside, [20] allamandin, [8] phytosphingosine, and [5] anacardic acid were the listed phytochemicals with pharmaceutical activities.

Table 2: Compounds identified in HPGS using QTOF-LC/MS analysis.

\begin{tabular}{|c|c|c|c|c|}
\hline No. & Compounds & $\begin{array}{l}\text { Reported as } \\
\text { phytochemical }\end{array}$ & $\begin{array}{l}\text { Reported with } \\
\text { pharmaceutical activities }\end{array}$ & Reference and remark \\
\hline 1. & Thymine & No & No & It is a pyrimidine nucleobase. \\
\hline 2. & cis-Fenpropimorph & No & No & $\begin{array}{l}\text { It is a morpholine-derived fungicide. } \\
\text { Zenebe } \text { et } \text { al. [19] }\end{array}$ \\
\hline 3. & Albendazole (V) & No & Yes & $\begin{array}{l}\text { It is an antihelmintic agent used predominantly } \\
\text { in treatment of echinococcosis. }\end{array}$ \\
\hline 4. & tetranor-PGEM & No & No & It is a metabolite of $\mathrm{PGE}_{1}$ or $\mathrm{PGE}_{2}$. \\
\hline 5. & Cyclic de-hypoxanthine futalosine & No & No & - \\
\hline 6. & $\begin{array}{l}\text { 5,3', } 4^{\prime} \text {-Trihydroxy-7-methoxy-4-phenylcoumarin } \\
\text { 5-O-(6"-acetyl)-galactoside }\end{array}$ & Yes & Yes & $\begin{array}{l}\text { Korec et al. [20] } \\
\text { It is a type of neoflavonoids which exerts } \\
\text { anti-diabetic effect in vivo }\end{array}$ \\
\hline 7. & Arg Ala Ala & No & No & $\begin{array}{l}\text { It is a tripeptide. } \\
\text { Johnston }[21] \text {. }\end{array}$ \\
\hline 8. & Picrotoxinin & No & Yes & $\begin{array}{l}\text { It is a convulsant drug acting as } \mathrm{GABA}_{\mathrm{A}} \\
\text { receptor antagonist. } \\
\text { Kuigoua et al. [22] }\end{array}$ \\
\hline 9. & Allamandin & Yes & Yes & $\begin{array}{l}\text { It is an iridoid lactone showing antifungal, } \\
\text { antialgal, and/or antibacterial activities. }\end{array}$ \\
\hline 10. & Erythronolide B & No & No & It is an intermediate of erythromycin biogenesis. \\
\hline 11. & 9-hydroperoxy-12,13-epoxy-10-octadecenoic acid & Yes & No & It is a long-chain fatty acid. \\
\hline 12. & Kanamycin & No & Yes & $\begin{array}{l}\text { It is an aminoglycoside bacteriocidal antibiotic. } \\
\text { Pavicic et al. [23] }\end{array}$ \\
\hline 13. & Phytosphingosine & Yes & Yes & $\begin{array}{l}\text { It is a phospholipid with anti-microbial and } \\
\text { anti-inflammatory activities. }\end{array}$ \\
\hline 14. & Eicosanedioic acid & Yes & No & It is a long-chain fatty acid. \\
\hline 15. & \pm 11 -HEDE & Yes & No & It is a long-chain fatty acid. \\
\hline 16. & 4,14-Dimethyl-hexadecanoic acid & Yes & No & It is a long-chain fatty acid. \\
\hline 17. & 3-O-L-rhamnosyl-3-hydroxydecanoyl-3-hydroxydecanoic acid & Yes & No & $\begin{array}{l}\text { It is a long-chain fatty acid. } \\
\text { Hemshekhar et al. [24] }\end{array}$ \\
\hline 18. & Anacardic acid & Yes & Yes & $\begin{array}{l}\text { It has been applied for alexeritic, amebicidal, } \\
\text { gingivitis, malaria and syphilitic ulcers in Ayurveda }\end{array}$ \\
\hline 19. & 1-Oleoyl-2-acetyl-sn-glycerol & No & No & - \\
\hline 20. & (24S,25R)-25,26-epoxy-1 $\alpha, 24$-dihydroxy-27-norvitamin D3 & Yes & No & It is a lipid derivative. \\
\hline 21. & $\begin{array}{l}\text { 1 } \alpha, 25 \text {-dihydroxy-24a,24b,24c-trihomovitamin D3/1 } \\
25 \text {-dihydroxy-24a,24b,24c-trihomocholecalciferol }\end{array}$ & Yes & No & It is a lipid derivative. \\
\hline 22. & Neomycin B & No & No & It is an aminoglycoside bacteriocidal antibiotic. \\
\hline 23. & $\begin{array}{l}\text { 4,4-dimethyl-14alpha-hydroxymethyl-5alpha-cholesta-8-en- } \\
\text { 3beta-ol }\end{array}$ & Yes & No & It is a triterpene. \\
\hline 24. & 2- tricosanamidoethanesulfonic & No & No & - \\
\hline 25. & Zymosterol intermediate $1 \mathrm{c}$ & No & No & - \\
\hline
\end{tabular}




\begin{tabular}{|c|c|c|c|c|}
\hline No. & Compounds & $\begin{array}{l}\text { Reported as } \\
\text { phytochemical }\end{array}$ & $\begin{array}{l}\text { Reported with } \\
\text { pharmaceutical activities }\end{array}$ & Reference and remark \\
\hline 26. & $\begin{array}{l}\text { MID42417:(22R)-1 } \alpha, 22,25 \text { - trihydroxy-26,27-dimethyl- } \\
\text { 23,23,24,24-tetradehydro- 24a,24b-dihomovitamin D3 }\end{array}$ & Yes & No & It is a lipid derivative. \\
\hline 27. & $2 \alpha$-(3-Hydroxypropyl)-1 $\alpha, 25$ - dihydroxy-19-norvitamin D3 & Yes & No & It is a lipid derivative. \\
\hline 28. & Haplophytine & No & No & - \\
\hline 29. & 6-Deoxotyphasterol & Yes & No & It is a sterol. \\
\hline 30. & Ergosta-3beta,5alpha,6beta,25-tetrol & Yes & No & It is a sterol. \\
\hline 31. & 2 $\alpha$-(3-Hydroxypropyl)-1 $\alpha, 25$-dihydroxy-19-norvitamin D3 & Yes & No & It is a lipid derivative. \\
\hline 32. & Mestanolone & No & No & - \\
\hline 33. & 12,15-epoxy-13,14-dimethyleicosa-12,14-dienoic acid & Yes & No & It is a long-chain fatty acid \\
\hline 34. & Sugeonyl acetate & Yes & No & Anti-inflammation \\
\hline 35. & $\begin{array}{l}\text { MID42417:(22R)-1 } \alpha, 22,25 \text {-trihydroxy-26,27-dimethyl- } \\
\text { 23,23,24,24-tetradehydro-24a,24b-dihomovitamin D3 }\end{array}$ & Yes & No & It is a lipid derivative. \\
\hline 36. & Pyrimidine -2,4 $(1 \mathrm{H}, 3 \mathrm{H})$-dione, 5-amino-6-nitroso & No & No & - \\
\hline
\end{tabular}

\section{CONCLUSION}

HPGS contains natural constituents, such as alkaloids, saponins, and flavonoids, without significant toxicity at $300 \mathrm{mg} /$ $\mathrm{kg}$ consumption.

\section{ACKNOWLEDGMENT}

This work is supported under CUCMS Research Grant Scheme (CRGS).

\section{CONFLICT OF INTEREST}

Authors declared that they do not have any conflicts of interest.

\section{REFERENCES}

1. Pramanick DD. Anatomical studies on the leaf of Gymnema sylvestre (Retz.) R.Br. ex Schult. (Apocynaceae): a magical herbal medicine for diabetes. Int J Herb Med 2016;4:70-2.

2. Saneja A, Sharma C, Aneja KR, Pahwa R. Gymnema sylvestre (Gurmar): a review. Pharmacia Lett 2010;2:275-84.

3. Jonas WB, TJ Kaptchuk, K Linde. A critical overview of homeopathy. Ann Intern Med 2003;138:393-9.

4. Kanetkar P, Singhal R, Kamat M. Gymnema sylvestre: a memoir. J Clin Biochem Nutr 2007;41:77-81.

5. Prajval ER, Girija K, Lakshman K, Bhat V. Gymnema sylvestre R. Br: a comprehensive review on phytochemical and analytical study. Int $\mathrm{J}$ Pharmacognosy 2018;3:136-43.

6. Surender S, Rohit K, Ritu K, Prerna K, Shalu R, Debadatta N, Gupta YK. Evaluation of safety profile of homoeopathic mother tinctures. Indian J Res Homoeopathy 2014;8:81-6.

7. Poonkothai M, Selvi S. Phytochemical screening and antioxidant assay of Agaricus bisporous (white button mushroom). Int J Biol Pharm Res 2015;6:877-84.

8. Ogawa Y, Sekita K, Umemura T, Saito M, Ono A, Kawasaki Y, et al. Gymnema sylvestre leaf extract: a 52-week dietary toxicity study in Wistar rats. Shokuhin Eiseigaku Zasshi 2004;45:8-11.

9. Mazid M, Khan TA, Mohammad F. Role of secondary metabolites in defense mechanisms of plants. Biol Med, 2011;3:232-49.

10. Njeru SN, Matasyoh J, Mwaniki CG, Mwendia CM, Kobia GK. A review of some phytochemicals commonly found in medicinal plants. Int J Med Plants 2013;105:135-40.

11. Singh K, Deo B. Phytochemical evaluation and in vitro antioxidant activity of Gymnema sylvestre R. Br J Med Plants Stud 2014;2:19-23.

12. Pingale S, Rupanar S, Chaskar M. Physico-chemical composition, phytochemical analysis and in vitro antioxidant activity of Gymnema sylvestre root. J Nat Prod Plant Resour 2016;6:1-7.

13. Bribi N. Pharmacological activity of alkaloids: a review. Asian J Bot 2018; $1: 467$
14. de Almeida ACA, de-Faria FM, Dunder RJ, Manzo LPB, Souza-Brito ARM, Luiz-Ferreira A. Recent trends in pharmacological activity of alkaloids in animal colitis: potential use for inflammatory bowe disease. Evid Based Complement Alternat Med 2017;2017:8528210.

15. Chaves SK, Feitosa CM, da S Araújo L. Alkaloids pharmacological activities-prospects for the development of phytopharmaceuticals for neurodegenerative diseases. Curr Phar Biotechnol 2016;17:629-35.

16. Roy A. A review on the alkaloids an important therapeutic compound from plants. Int J Plant Biotechno 2017;3:1-9.

17. Panche AN, Diwan AD, Chandra SR. Flavonoids: an overview. J Nutr Sci 2016;5:e47.

18. Tiwari P, Mishra BN, Sangwan NS. Phytochemical and pharmacological properties of Gymnema sylvestre: an important medicinal plant. BioMed Res Int 2014;2014:830285.

19. Zenebe S, Feyera T, Assefa S. In vitro anthelmintic activity of crude extracts of aerial parts of Cissus quadrangularis L. and leaves of Schinus molle L. against Haemonchus contortus. BioMed Res Int 2017;2017:1905987.

20. Korec R, Heinz Sensch K, Zoukas T. Effects of the neoflavonoid coutareagenin, one of the antidiabetic active substances of Hintonia latiflora, on streptozotocin-induced diabetes mellitus in rats. Arzneimittelforschung 2000;50:122-8.

21. Johnston GA. Advantages of an antagonist: bicuculline and other GABA antagonists. Br J Pharmacol 2013;169:328-36.

22. Kuigoua GM, Kouam SF, Ngadjui BT, Schulz B, Green IR, Choudhary MI, et al. Minor secondary metabolic products from the stem bark of Plumeria rubra Linn. displaying antimicrobial activities. Planta Med 2010;76:620-5.

23. Pavicic T, Wollenweber U, Farwick M, Korting HC. Anti-microbial and-inflammatory activity and efficacy of phytosphingosine: an in vitro and in vivo study addressing acne vulgaris. Int J Cosmet Sci 2007;29:181-90.

24. Hemshekhar M, Santhosh MS, Kemparaju K, Girish KS. Emerging roles of anacardic acid and its derivatives: a pharmacological overview. Basic Clin Pharmacol Toxico 2011;110:122-32.

25. Chodisetti B, Rao K, Giri A. Phytochemical analysis of Gymnema sylvestre and evaluation of its antimicrobial activity. Nat Prod Res 2013;7:583-7.

\section{How to cite this article:}

Shukla A, Muhammed IK, Sheshala R, Mhaisker IU, Rampal $\mathrm{K}$. Acute toxicity evaluation of homeopathic preparation of Gymnema sylvestre and analysis of its chemical constituents. J Appl Biol Biotech 2020;8(04):033-037. DOI: 10.7324/ JABB.2020.80405 